\title{
Application of Fuzzy Logic in Making Automatic Labeling Stamping
}

\author{
Ondra Eka Putra, S.Kom, M.Kom \\ Universitas Putra Indonesia YPTK Padang \\ Jl. Raya Lubuk Begalung Padang \\ Sumatera Barat \\ Email : ondraekaputra17@gmail.com
}

\begin{abstract}
This research was conducted to create a labeling system on cardboard boxes with automatic stamping. Labeling is done based on height and weight of the cardboard so that stamping will be done according to the size and weight of the cardboard. The height of the cardboard is detected using an ultrasonic sensor and the weight of the cardboard is detected using a load cell sensor, and a stepper motor to move the cardboard label stamping. This research is based on artificial intelligence using mamdani method with fuzzy logic, so that all data can be processed properly. The height of the cardboard detected by the ultrasonic sensor is given a distance value of $10 \mathrm{~cm}$ to $45 \mathrm{~cm}$ with a value of rendah, sedang and tinggi. Cardboard weight detected by load cell sensor is given a weight value of $500 \mathrm{gr}$ up to 1,500 gr with ringan, sedang and berat values. Stamping labels are driven by stepper motors which are given time values of 5 $\mathrm{s}$ to $15 \mathrm{~s}$ with time values of sebentar, sedang, and lama After the ultrasonic sensor and the load cell detect the cardboard box, the conveyor belt moves to run the cardboard box by the power window motor, then if the cardboard box passes through the proximity sensor, the conveyor belt stops and the stepper motor moves to stamping the cardboard label box automatically. The label stamping system is controlled by using the Arduino Mega 2560 to work well.
\end{abstract}

Keyword-Artificial Intelligence, Mamdani Method, Fuzzy Logic, Stamping Labeling, Arduino Mega 2560, Fuzzy Inference System

\section{INTRODUCTION}

A process of producing goods carried out by companies, groups or individuals will always give a label to the goods produced either by using stickers or by stamping on each item of goods or on packing of goods. One packs goods produced using cardboard to make it safer, so cardboard packing needs to be labeled for goods information. Packing boxes of goods are usually made in many sizes, small, medium or large. Labeling items on cardboard packaging can be used by sticking a sticker or stamping manually or automatically. Giving labels of goods that require low cost, namely the provision of stamping labels on goods so as to reduce the cost of producing goods rather than in the form of stickers. Giving stamping labels done manually will certainly require a long time and a high error rate including reverse labeling,

inaccurate or other non-technical errors, then a stamping label system that can work automatically can be made which can reduce working time and errors will occur.

Making stamping labels is based on the height and weight of the cardboard so that stamping will be done according to the size and weight of the cardboard. The height of the cardboard is detected using an ultrasonic sensor and the weight of the cardboard is detected using a load cell sensor, and a stepper motor to move the cardboard label stamping. Classical control theory is based on the mathematical models that describe the physical plant under consideration. The essence of fuzzy control is to build a model of human expert who is capable of controlling the plant 
without thinking in terms of mathematical model. Automatic label stamping is created by applying artificial intelligence using mamdani method with fuzzy logic control, so that all data can be processed properly. Fuzzy logic is logic that has a partial truth concept, where fuzzy logic allows membership values between 0 and 1 (Husein, A M, 2014). After the ultrasonic sensor and the load cell detect the cardboard box, the conveyor belt moves to run the cardboard box by the power window motor, then if the cardboard box passes through the proximity sensor, the conveyor belt stops and the stepper motor moves to stamping the cardboard label box automatically. The label stamping system is controlled using the Arduino Mega 2560 to work well.

\section{LITERATURE REVIEW}

\subsection{Fuzzy Logic}

Fuzzy logic was first introduced in 1965 by Prof. Lutfi A. Zadeh, a researcher at the University of California at Barkley in the field of computer science. Professor Zadeh assumed that logic of right and wrong could not represent every human thought, then fuzzy logic was developed which could represent every state or represent human thought. The difference between strict logic and fuzzy logic lies in the membership of elements in a set. If in strict logic an element has two choices which are contained in the set or value 1 which means true and not on the set or value 0 which means false. Whereas in fuzzy logic, element membership is in the interval $[0,1]$ (Kusumadewi, 2010).

\subsubsection{Fuzzy Association}

Fuzzy set is a development of firm set. A strict set is a set whose membership value of the element has only two possible degrees of membership, namely:

$$
\mu_{A}(x)=\left\{\begin{array}{c}
1 ; \text { jika } x \in A \\
0 ; \text { jika } x \notin A
\end{array}\right.
$$

Symbols $\mu_{\mathrm{A}}$ are characteristic functions of sets. Whereas in fuzzy set the degree of membership for each element is located in the interval $[0,1]$.

\subsubsection{Membership Function}

The membership function is a function that maps elements of a set to membership values at intervals $[0,1]$. A membership function that distinguishes fuzzy sets from explicit sets. Membership functions can be represented in various ways, but the most common and widely used in systems that are based on fuzzy logic is analytic representations. Appropriate modeling is needed because the fuzzy model is sensitive to the type of fuzzy set description. There are various types of fuzzy set descriptions, but the membership function used in the author's research is linear, triangular and trapezoidal representations (Tulus Pranata, 2015).

\section{A. Representation of linear curves}

The simplest representation in the membership function is a linear representation which is described as a straight line. There are two linear fuzzy sets.

First, the set has decreased from one degree of membership moving right towards a lower degree of membership toward zero. This is seen in Figure 1.

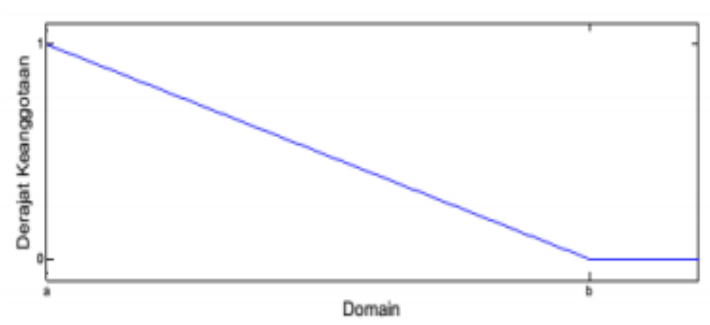

Fig. 1 Representation of the Linear Curve Down

The linear membership function is down:

$$
\mu(x)=\left\{\begin{aligned}
\frac{b-x}{b-a}, & a \leq x \leq b \\
0, & x \geq b
\end{aligned}\right.
$$

Information:

$\alpha=$ smallest domain value when the smallest degree of membership

$b=$ the largest degree of membership in the domain

Second, the set has increased from the degree of zero membership moving to the right towards a higher degree of membership towards one. This can be seen in Figure 2. 


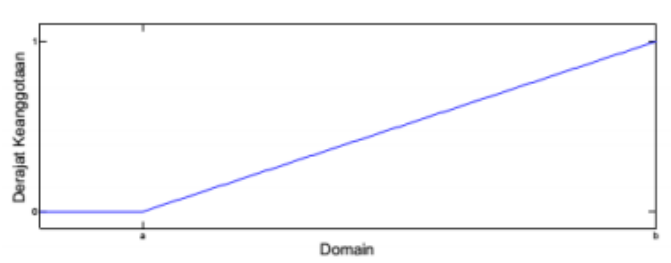

Fig. 2 Representation of the Linear Curve Rises

The linear membership function goes up:

$$
\mu(x)=\left\{\begin{aligned}
0, & x \leq a \\
\frac{x-a}{b-a}, & a \leq x \leq b \\
1, & x=b
\end{aligned}\right.
$$

Information :

$\alpha=$ smallest domain value when the smallest degree of membership

$b=$ the largest degree of membership in the domain

\section{B. Representation of triangle curves}

The triangular curve representation is a combination of linear representation (Klir, Clair \& Yuan, 1997: 83-86). Representation of the triangle curve can be seen in Figure 3.

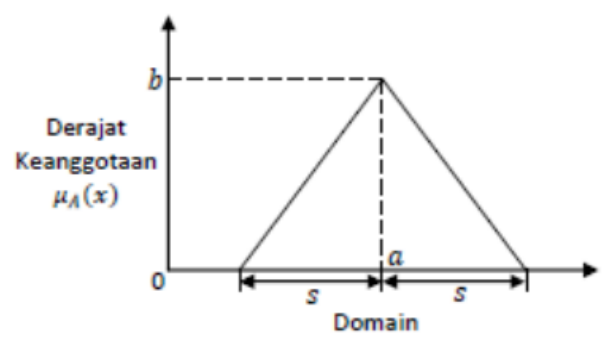

Fig. 3 Representation of Triangle Curves

The membership function of the triangle representation is:

$$
\mu(x)=\left\{\begin{aligned}
0, & x \leq a \text { atau } x \geq c \\
\frac{x-a}{b-a}, & a \leq x \leq b \\
\frac{c-x}{c-b}, & b \leq x \leq c
\end{aligned}\right.
$$

Information:

$\alpha=$ smallest domain value that has zero membership level

$$
\begin{aligned}
& b=\text { domain value that has one membership } \\
& \text { degree } \\
& c=\text { the largest domain value that has a zero } \\
& \text { membership degree }
\end{aligned}
$$

\section{Representation of the Trapezoid Curve}

Trapezoid curves are basically like triangles because they are a combination of two lines (linear), it's just that there are some points that have a membership value of 1 . The representation of the trapezoid curve is shown in the following figure.

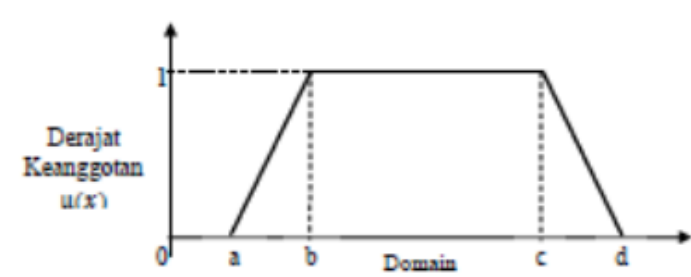

Fig. 4 Representation of the Trapezoid Curve

Membership Function:

$$
\mu[x]=\left\{\begin{array}{lr}
0 ; & x \leq a \text { atau } x \geq d \\
\frac{(x-a)}{(b-a)} ; & a \leq x \leq b \\
1 ; & b \leq x \leq c \\
\frac{(d-x)}{(d-c)} ; & x \geq d
\end{array}\right.
$$

Information:

$\alpha=$ smallest domain value that has zero membership level

$b=$ smallest domain value that has a membership degree of one

$c=$ the value of the largest domain that has a degree of membership of one

$d=$ the value of the largest domain that has a zero membership degree

\subsubsection{Fuzzy Set Operations}

Like the set of express numbers, there are several operations that are specifically defined for combining and modifying fuzzy sets. The membership value is the result of the operation of two sets known as $\alpha$-predicates. According to Wang (1997: 29), there are three basic operations in the fuzzy set, namely complement, intersection and union. 


\section{a. Complement}

The complement operation on the fuzzy set is as a result of the operation with the NOT operator obtained by subtracting the membership value of the element in the set concerned from 1.

$$
\bar{A}(x)=1-A(x)
$$

\section{b. Intersection}

The intersection operation on the fuzzy set is the result of an operation with the AND operator obtained by taking the smallest membership value between elements in the set concerned.

$$
(\mathrm{A} \cap \mathrm{B})(\mathrm{x})=\min [\mathrm{A}(\mathrm{x}), \mathrm{B}(\mathrm{x})]
$$

c.

\section{Union}

The joint operation (union) on a fuzzy set is as a result of an operation with an OR operator obtained by taking the largest membership value between elements in the related sets.

$$
(A \cup B)(x)=\max [A(x), B(x)]
$$

\subsection{Fuzzy System}

The arrangement of the fuzzy system is shown in Figure 5.

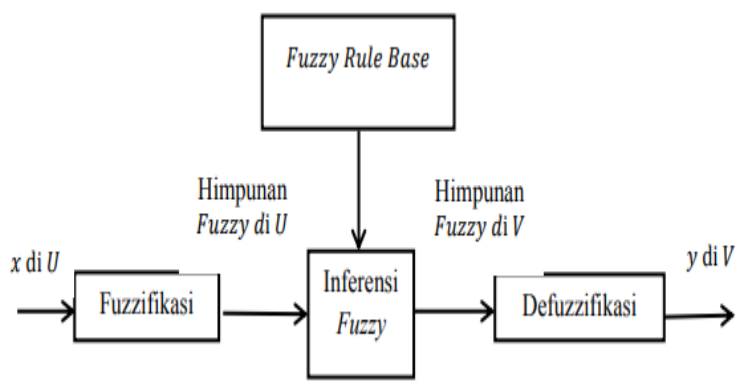

Fig. 5 Fuzzy System

Explanation of the stages of the fuzzy system is as follows:

\section{A. Fuzzification}

According to Wang (1997: 105), fuzzification is defined as a mapping from a firm set to a fuzzy set. The criteria that must be fulfilled in the fuzzification process are all members of the firm set must be contained in the fuzzy set, there are no disturbances to the input of the fuzzy system used should be able to simplify calculations on the fuzzy system.

\section{B. Fuzzy Rules}

The rules used in the fuzzy set are the if then rules. IF-THEN fuzzy rules are statements represented by

IF $<$ proposisi fuzzy $>$ THEN $<$ proposisi fuzzy $>$

\section{Fuzzy Inference}

Fuzzy inference is an evaluation stage in fuzzy rules. The evaluation phase is based on reasoning using fuzzy input and fuzzy rules so that the output is obtained in the form of a fuzzy set.

\section{Defuzzification}

Defuzzification is a process that is the opposite of the process of fuzzification. Wang (1997: 108) defines defuzzification as the mapping from fuzzy set (B) to firm set. Fuzzy set referred to here is the output obtained from the inference results. In the defuzzification process, there are three criteria that must be met, namely reasonable, simple and continuous calculation. Following are some of the methods used for the defuzzification process.

\section{RESEARCH METHODS}

The research method describes the research which consists of the steps that will be carried out within the framework of problem solving that will be discussed, such as Figure 6. 


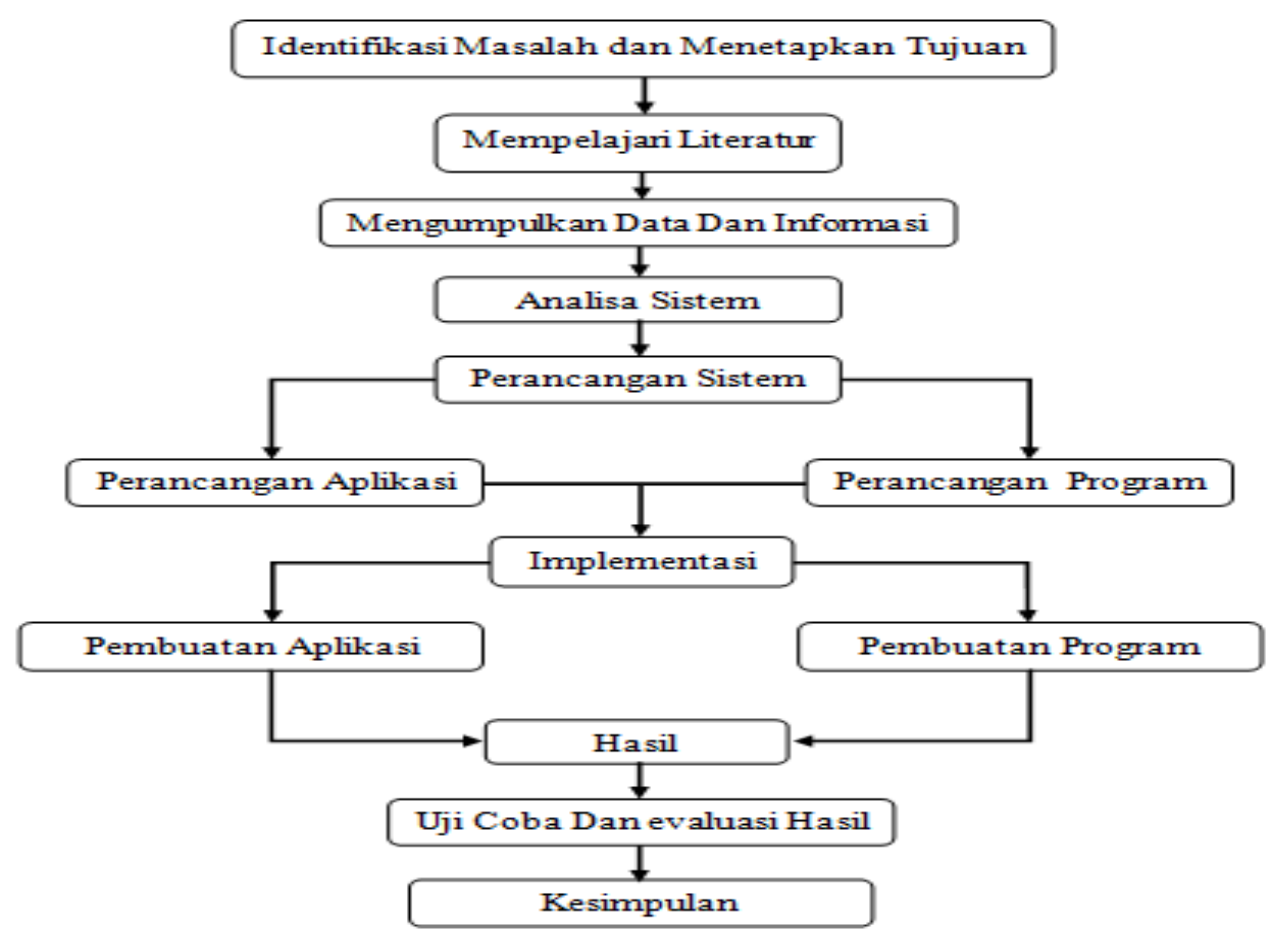

Fig. 6 Research methodology

The research methodology explains the stages carried out in order to solve the problem to be solved in the study. The first stage of conducting research is the identification of problems, the problems identified are that of manual stamping labels that take a long time and a high error rate. After the problem is identified continue studying the literature, collecting data and information needed in accordance with the problem to be solved. Data can be obtained from scientific journals, books, internet and field studies that support research. The next step is a system analysis to determine the system inputs, processes and outputs. After the next system analysis, system design, then system development, system testing and implementation.

\section{RESULTS AND DISCUSSION}

\subsection{Fuzzy Inference System (FIS)}

In determining the stamping label, fuzzy logic application is used to change the input in the form of height and weight of the cardboard so as to get the output in the form of stamping label movement. Then adjusted to the membership range on the label stamping variable so that it is obtained how long the stamping label movement. In determining the stamping label movement used Mamdani method or often also known as the Min - Max Method. In this method, each of the rules in the form of implications ("cause-effect") in the form of conjunctions in the form of conjunctions (AND) has a minimum membership value (min), while the consequent combination is in the maximum ( $\max$ ) form.

\subsubsection{Variabel Fuzzy / FIS Editor}

In the Mamdani Method, both input and output variables are divided into one or more fuzzy sets. In determining the stamping label movement, input variables are divided into two, namely the height and weight of the cardboard. As well as one output variable, which is the variable for how long the stamping label moves. Fuzzy variables consist of variables, sets, universe of talks and domains that can be seen in table 1 . 
Table 1 Fuzzy Variables

\begin{tabular}{|l|l|c|c|}
\hline Variables & Sets & $\begin{array}{c}\text { Universe } \\
\text { of Talk }\end{array}$ & Domains \\
\hline Height & Rendah & & $10 \mathrm{~cm}-$ \\
Sensor) & Tinggi & $10 \mathrm{~cm}-$ & $27.5 \mathrm{~cm}$ \\
& & $45 \mathrm{~cm}$ & $35 \mathrm{~cm}-$ \\
& & & $27.5 \mathrm{~cm}-$ \\
& & & $45 \mathrm{~cm}$ \\
\hline Weight & Ringan & & $500 \mathrm{gr}-$ \\
(Load Cell) & Sedang & $500 \mathrm{gr}-$ & $1.000 \mathrm{gr}$ \\
& Berat & 1.500 & $750 \mathrm{gr}-$ \\
& & $\mathrm{gr}$ & $1.250 \mathrm{gr}$ \\
& & & $1.000 \mathrm{gr}-$ \\
& & & $5 \mathrm{~s}-10 \mathrm{gr}$ \\
\hline Stamping & Sebentar & & $7.5 \mathrm{~s}-$ \\
Label & Sedang & & $12.5 \mathrm{~s}$ \\
(Stepper & Lama & $5 \mathrm{~s}-15 \mathrm{~s}$ & $10 \mathrm{~s}-15$ \\
Motor) & & & $\mathrm{s}$ \\
\hline
\end{tabular}

\subsubsection{Membership Function}

Membership function is a curve that shows the mapping of data input points into the value of membership or the degree of membership that has an interval between 0 to 1 . One way that can be used is through a function approach that can be used. Membership function can be seen in Figure 7.

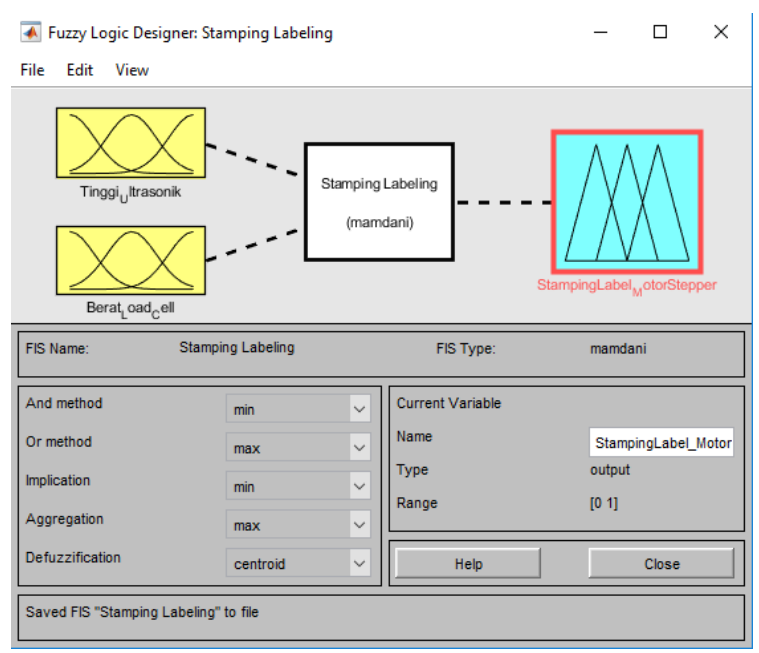

Fig. 7 Membership Function
Based on Figure 7 it can be seen that the membership function consists of 3 membership functions including Tinggi Ultrasonik, Berat Load Cell as input and Stamping Label Motor Stepper as output.

\subsubsection{Triangular Membership Function}

The membership function of a triangle is characterized by the presence of three parameters $\{a$, $b, c\}$ which will determine the $x$ coordinates of the three angles. This curve is basically a combination of two straight lines. The equations for the shape of this triangle are:

\section{Cardboard Height}

In the cardboard height variable, three fuzzy sets are defined, namely Rendah, Sedang and Tinggi. Variable height of cardboard can be seen in Figure 8 below:

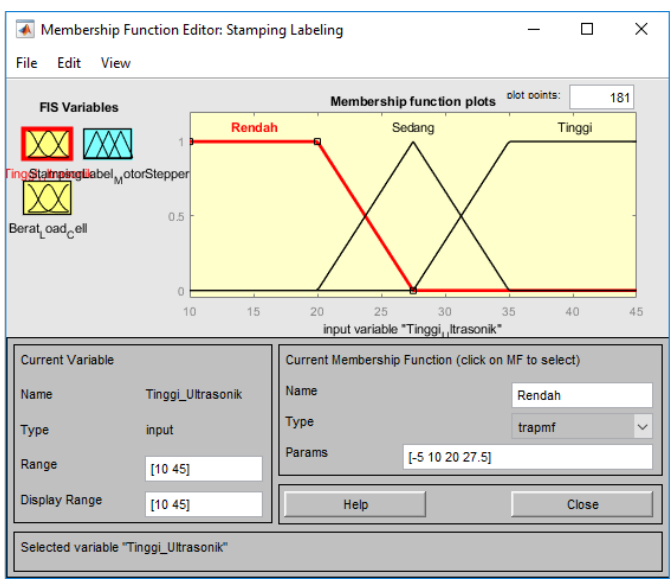

Fig. 8 Variable Height of Cardboard

Based on Figure 8 describes the membership set Tinggi Ultrasonik that is Rendah with parameters [51020 27.5], Sedang with parameters [20 27.5 35] and Tinggi with parameters [27.5 3545 50].

\section{Cardboard Weight}

In the cardboard weight variable three fuzzy sets are defined, namely Ringan, Sedang, and Berat. Variable cardboard weight can be seen in the following figure 9: 


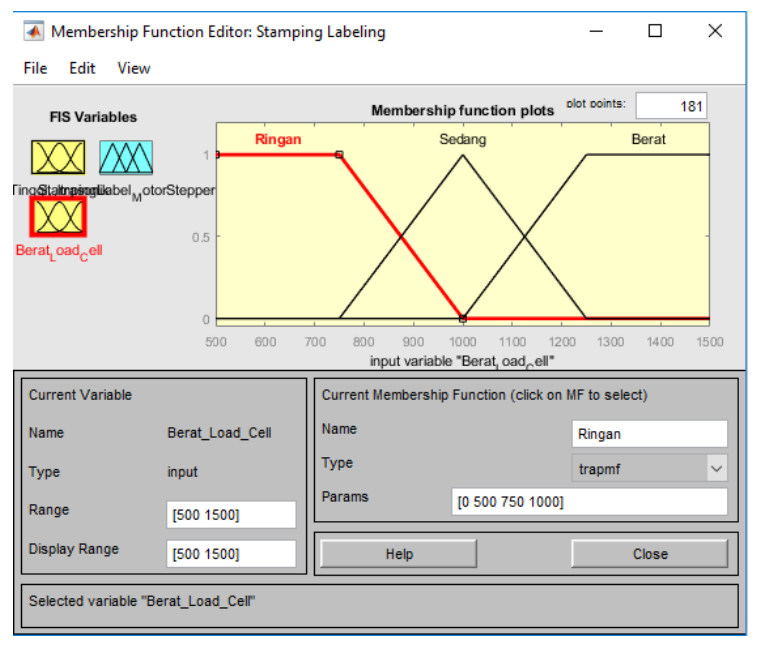

Fig. 9 Cardboard Weight Variables

Based on Figure 9 describes the membership set Berat Load Cell that is Ringan with parameters 0 500750 1000], Sedang with parameters [750 100 1250] and Berat with parameters [1000 12501500 2000].

\section{Stamping Label}

In the stamping variable label is defined as three fuzzy sets, namely Sebentar, Sedang and Lama. Variable weight of cardboard can be seen in Figure 10 below:

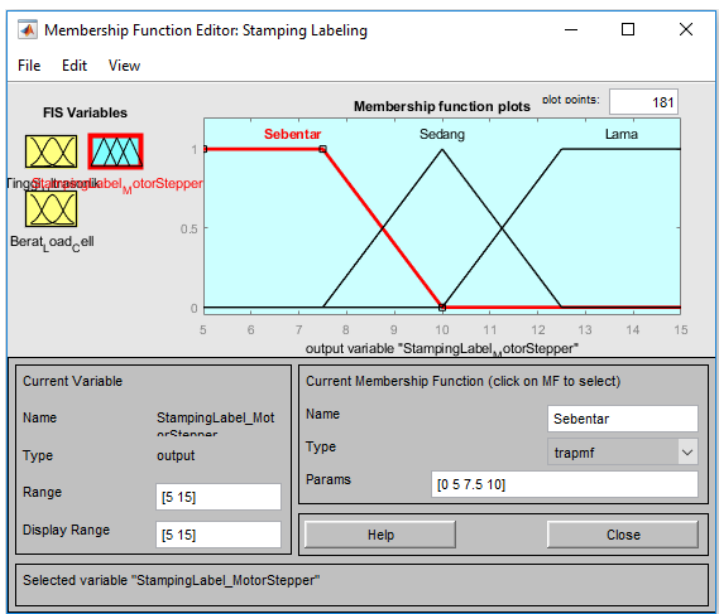

Fig. 10 Variable Stamping Label

Based on Figure 10 describes the membership set Stamping Label Motor Stepper is Sebentar with parameters [0 57.5 10], Sedang with parameters [7.5 10 12.5] and Lama with parameters [10 12.5 15 17.5].

\section{Rule Editor}

Rule editor label stamping can be seen in the following image:

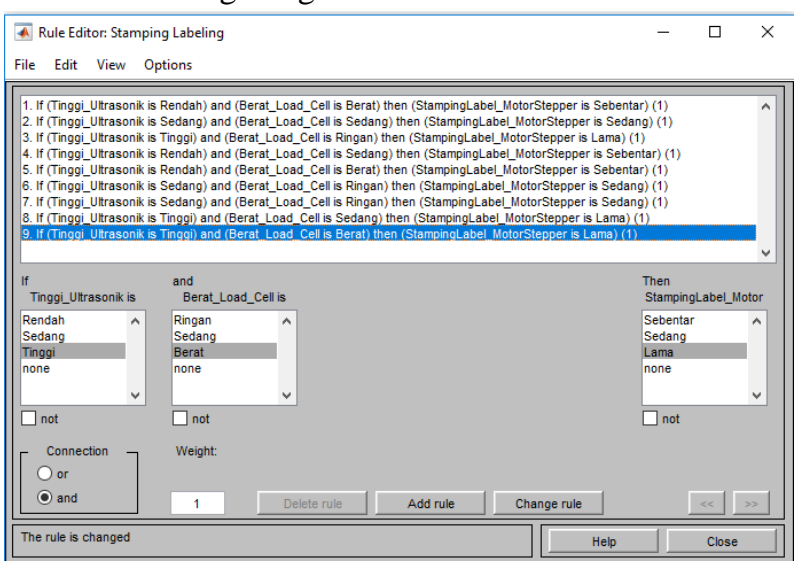

Fig. 11 Rule Editor

\subsection{Context Diagram}

Context diagram is a definition of the system to be designed that is overall. Serves to facilitate the process of analyzing the system as a whole which consists of a process and several external entities. Figure context diagram can be seen in Figure 12.

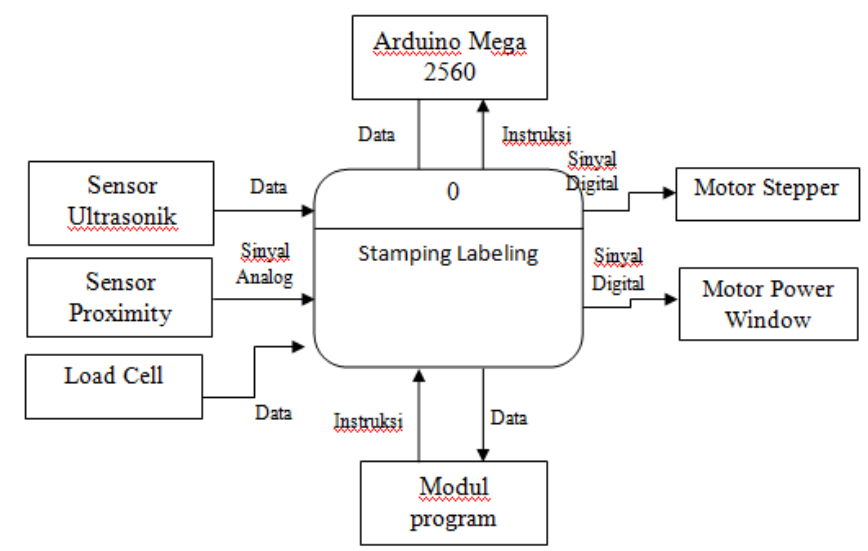

Fig. 12 Context Diagram

Based on Figure 11 explains that this system interacts with several entities which will be discussed below, the following types of entities are used:

a. Ultrasonic Sensor

Ultrasonic sensors function to detect the size of existing cardboard.

b. Proximity Sensor 


\section{Cin Journal Publications \& Informatics Engineering Research

Proximity sensor functions to detect passing cardboard.

c. Power Window Motor

Motor power window functions as a conveyor belt drive.

d. Load Cell

Load Cell has a function to detect cardboard weight.

e. Stepper Motor

Stepper motor functions as a label stamp drive.

f. Arduino Mega 2560

Arduino Mega 2560 is the basis of the controller of the system.

g. Program module

Program modules are used to process data.

\subsection{System Testing}

System testing is done to see how far the system can run well. System testing can be seen in the following picture:

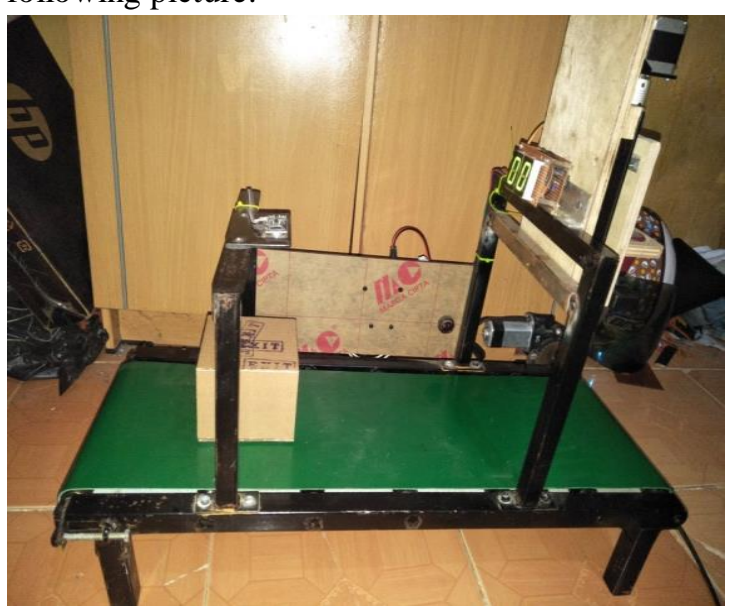

Fig. 13 Cardboard Initial Position

Based on Figure 13, the automatic labelingcardboard stamping system is placed above the conveyor belt, then the ultrasonic sensor will read the height of the cardboard and the load cell sensor will read the weight of the cardboard.

After the ultrasonic sensor and the load cell detect the cardboard then the motor power window is active to run the conveyor belt to run the cardboard, when the cardboard moves and is detected by the proximity sensor the motor power window is inactive so the conveyor belt is not running, as can be seen in the following figure:

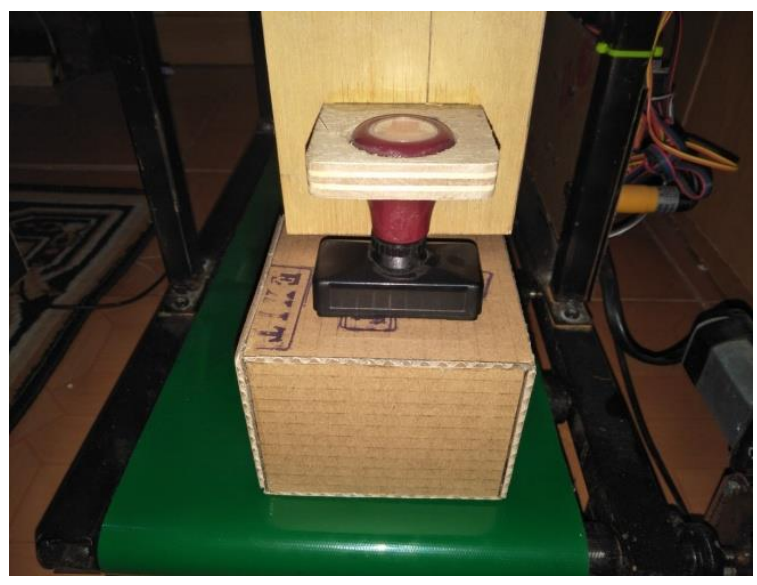

Figure 14 Label Stamping Process

After the conveyor belt does not run then the stepper motor will actively move the stamping label downward according to the height and weight of the cardboard, as shown in Figure 14.

\section{CONCLUSION}

Based on the test results the system can be concluded as follows: that by using fuzzy logic can work effectively for reading height and weight of cardboard that is uncertain to provide a decision to move the stamping label by using a stepper motor based on height and weight of cardboard.

\section{REFERENSI}

Husein, A M. Model Manajemen Persediaan Berdasarkan Permintaan Menggunakan Teknik Fuzzy Mamdani. Jurnal Teknik Informatika Prima, ISSN 2088-6102, Vol 7, No 2, Oktober 2014.

Awal, H., \& Putra, O. E. (2018). Aplikasi Knowledge Base System dalam Perancangan Learning Machine. SinkrOn, 3(1), 1-7.

Putra, O. E., \& Febrianti, E. L. (2017). Analisa Jumlah Produksi Pada Industri Rumah Tangga Dengan Menggunakan Logika Fuzzy: Studi Kasus Ud Tempe Puji Kecamatan Bayang Kabupatern Pesisir Selatan. Sainstek: Jurnal Sains dan Teknologi, 8(2), 173-179.

Putra, O. E. (2017). Aplikasi Artificial Inttelegence Pada Public Territory Room Berbasis Mikrokontroler (Study Kasus: Ruangan Perkuliahan Upi-Yptk Padang). Jurnal 
Teknologi Informasi dan Pendidikan, 10(1), 53-59.

Buana, W. (2015). Penerapan Fuzzy Mamdani Untuk

Sistem Pendukung Keputusan Pemilihan

Telepon Seluler. Jurnal Edik Informatika.

Zulfikar, W. B., Prasetyo, P. K., \& Ramdhani, M. A.

(2018, January). Implementation of mamdani fuzzy method in employee promotion system. In IOP Conference Series: Materials Science and Engineering (Vol. 288, No. 1, p. 012147). IOP Publishing.

Sakti, I. (2014, November). Methodology of fuzzy logic with mamdani fuzzy models applied to the microcontroller. In 2014 The 1st International Conference on Information Technology, Computer, and Electrical Engineering (pp. 93-98). IEEE.

Pranata, T., \& Beni Irawan, I. (2015). Penerapan Logika Fuzzy pada Sistem Penyiraman Tanaman Otomatis Berbasis Mikrokontroler. Jurnal Coding Sistem Komputer Universitas Tanjungpura, 3(2).

Kusumadewi, S. \& Purnomo, H.(2010). Aplikasi Logika Fuzzy untuk Pendukung Keputusan. Yogyakarta:Graha Ilmu.

Supani, A., \& Azwardi, A. (2015). Penerapan Logika Fuzzy dan Pulse Width Modulation untuk Sistem Kendali Kecepatan Robot Line Follower. INKOM Journal, 9(1), 1-10. 